\begin{abstract}
Iranica
Abstracta Iranica Revue bibliographique pour le domaine irano-aryen

Volume 32-33 | 2013

Comptes rendus des publications de 2009-2010
\end{abstract}

\title{
Antonio Invernizzi. Nisa Partica. Le sculture ellenistiche
}

\section{Carlo Lippolis}

\section{(2) OpenEdition \\ 12 Journals}

\section{Electronic version}

URL: http://journals.openedition.org/abstractairanica/40522

DOI: 10.4000/abstractairanica.40522

ISSN: 1961-960X

\section{Publisher:}

CNRS (UMR 7528 Mondes iraniens et indiens), Éditions de l'IFRI

\section{Printed version}

Date of publication: 1 December 2013

ISSN: 0240-8910

\section{Electronic reference}

Carlo Lippolis, « Antonio Invernizzi. Nisa Partica. Le sculture ellenistiche », Abstracta Iranica [Online], Volume 32-33 | 2013, document 175, Online since 01 July 2016, connection on 01 October 2020. URL http://journals.openedition.org/abstractairanica/40522; DOI : https://doi.org/10.4000/ abstractairanica.40522

This text was automatically generated on 1 October 2020 .

Tous droits réservés 


\title{
Antonio Invernizzi. Nisa Partica. Le sculture ellenistiche
}

\author{
Carlo Lippolis
}

\section{REFERENCES}

Antonio Invernizzi. Nisa Partica. Le sculture ellenistiche. Firenze, Le Lettere, 2009, 180 p., XXIII colour pls. (Monografie di Mesopotamia XI)

1 This volume figures in a series published as part of a project at the Centro Scavi di Torino that seeks to (re)analyze the artefacts found at old Nisa and thus update earlier publications by Jutake. The marble sculptures from old Nisa figure among the most significant pieces of Hellenized eastern art. Although some of them had been the subject of previous studies, no systematic study has yet been made of all of them. This volume provides a new catalog of all the marble sculptures (including fragments that are presented herein for the first time) from Old Nisa with photographs.

2 Invernizzi describes these sculptures in detail and their classification, in particular from an iconographic point of view. He insists on the close affiliation of these sculptures, which were probably produced locally, with Hellenistic arts. But he also emphasizes the originality of certain features in comparison with the Mediterranean world; these artists made original, meaningful variations on the motifs and styles of Hellenistic sculpture, whence the assumption that excellent Asian-Greek workshops and sculptors were working for the Asian royal courts in central Asia.

Invernizzi also speculates on the significance that such sculptures might have had for royal clients, and relates these images (Greek gods displayed in a shrine in Arsacid Nisa) to the Iranian cultural and religious environment. 


\section{AUTHORS}

\section{CARLO LIPPOLIS}

Università di Torino 